\title{
NANOPARTICLES FROM ONION (ALLIUM CEPA.L) EXTRACT SUPPRESS BCL-2 EXPRESSION IN MCF-7 CELLS IN VITRO
}

\author{
Jayanti Shara*, Suseno Dewi Nurmalita, Suseno Dewi Alima Nostalia \\ Marine Fisheries Polytechnic, Sidoarjo, East Java, Indonesia \\ *E-mail: sharajayanti@gmail.com
}

\begin{abstract}
This research aimed to make nanoparticles from Allium cepa. $L$ extract that can inhibit $B c l-2$ protein expression in MCF-7 cells in vitro. The particles were broken down to nano with the addition of NaTPP dissolved in distilled water and chitosan dissolved in $1 \%$ acetic acid. The particle size based on the SEM and PSA tests had an average size of $336 \mathrm{~nm}$. Nanoparticles from Allium cepa. L extract based on the KLT test contained flavonoids, saponins, and tannins. MCF-7 cells were treated with doses of $40 \mu \mathrm{g} / \mathrm{ml}, 80 \mathrm{ug} / \mathrm{ml}, 160 \mathrm{ug} / \mathrm{ml}$, and 320 $\mathrm{ug} / \mathrm{ml}$. The results showed that nanoparticles from Allium cepa. L extract had cytotoxicity in MCF-7 cells with the IC50 value of $235 \mu \mathrm{g} / \mathrm{ml}$ and proved to inhibit Bcl-2 protein expression.
\end{abstract}

\section{KEY WORDS}

Allium cepa L, nanoparticles extract, Bcl-2, MCF-7.

Breast cancer refers to cancers originating from the mammary gland, glandular tissue, and breast supportive tissue. Besides, breast cancer has been reported to attack some animals, particularly productive adult female dogs [1,2]. The high incidence of breast cancer results in various treatment. In this research, a breakdown method for drug particles in cancer therapy was developed to enhance the ability of drug release.

Nanoparticles have higher drug release ability than drugs with general particle size. Nanoparticles from Allium cepa. $L$ have active compounds such as flavonoids, saponins, tannins and other compounds such as vitamins (B1, B2, and C), sodium, potassium, phosphorus, and others [3].

Flavonoids in Allium cepa. $\mathrm{L}$ act as antioxidants that can prevent oxidation, stabilize free radicals formed by carcinogenic compounds, and inhibit the production of heat shock proteins causing drug resistance in cancer therapy. Thus, drugs for cancer therapy derived from plant extracts have been used as an alternative therapy to prevent the negative reaction and inhibit anti-apoptotic protein with safe doses [4]. Flavonoids can induce apoptotic cells [5].

In addition to flavonoids, saponins have immunomodulatory activities and ability to inhibit the proliferation of cancer cells. Tannins also have the potential as antioxidants $[6,7]$ Saponins and tannins are coined as effective phytochemical agents. Saponins are composed of one or more hydrophilic glycoside moieties along with a lipophilic and derived aglycone and finally one or more sugar chains. Saponins interfere with the replication of cellular DNA and prevent the proliferation of cancer cells. Tannins are of polyphenolic nature. The features distinguishing tannins from plant-based polyphenols of other types are basically the properties of the binding of the former to proteins, basic compounds, pigments, largemolecular compounds, and metallic ions and also the display of anti-oxidant activities [8]. Saponins have immunomodulatory potential via cytokine interplay [9].

$\mathrm{Bcl}-2$ is anti-apoptotic proteins. Bcl-2 overexpression inhibits TRAIL-induced apoptosis in neuroblastoma, glioblastoma, and breast carcinoma cells [10].

\section{METHODS OF RESEARCH}

Allium cepa. $\mathrm{L}$ were collected and cut into small pieces. Allium cepa. $\mathrm{L}$ slices were dried in the room for 7 days, dried again in the oven at $50^{\circ} \mathrm{C}$, and then powdered using a mechanical blender. 148 grams of this powder was extracted using the maceration method 
with $70 \%$ ethanol for $24 \mathrm{~h}$. The obtained extracts were put to vacuum evaporator for evaporation of the excess solvent.

Allium cepa. L's nanoparticles were prepared by ionic gelation method. 1 gram of Allium cepa. L's extract was taken and put into the Duran tube. It was added with $35 \mathrm{ml}$ of ethanol and $15 \mathrm{ml}$ of distilled water. Then, a $1 \%$ chitosan solution diluted in $100 \mathrm{ml}$ of $1 \%$ acetic acid was added. A 0,001\% NaTPP solution diluted in $350 \mathrm{ml}$ of distilled water was added slowly while being rotated with the magnetic stirrer for $2 \mathrm{~h}$. Nanoparticles preparation was conducted in the Clinical Pathology Laboratory, Faculty of Veterinary, Airlangga University.

Nanoparticles were put in vacuum evaporator for evaporation of the excess solvent for $24 \mathrm{~h}$. The obtained extracts were put to vacuum evaporator for evaporation of the excess solvent and finally, these nanoparticles were freeze-dried to maintain the stability.

Flavonoids, saponins, and tannins are phytochemical compounds. The qualitative phytochemical screening of $500 \mathrm{mg}$ of nanoparticles from Allium cepa. L extract diluted in 1 $\mathrm{ml}$ of $70 \%$ ethanol was performed using TLC. The mobile phase used $\mathrm{n}$-hexane ethyl acetate at $8: 2$ ratio of $2 \mathrm{ml}$.

Spray reagents used were ammonia for flavonoids detection, anisaldehyde for saponins detection, and $\mathrm{FeCl}_{3}$ for tannins detection. The results were observed visually under UV light at $366 \mathrm{~nm}$.

Particle size analysis of Allium cepa. L's nanoparticles was conducted by Particle Size Analyzer (PSA) using Malvern Zetasizer Nano series Nano ZS (Malvern Instruments Ltd.)

Scanning electron microscopy of Allium cepa. L nanoparticles was conducted using Carl Zeiss (Evo MA 10) English.

Breast cancer cell line used in this research was the Michigan Cancer Foundation-7 (MCF-7) cell line. Cells were cultured in Dulbecco's Modified Eagle's Medium (DMEM) medium supplemented with $10 \% \mathrm{FBS}, 2 \%$ penicillin and streptomycin, and $0,5 \%$ fungizone at $37^{\circ} \mathrm{C}$ in the incubator containing $5 \% \mathrm{CO}_{2}$.

First, the sample used as a therapy for MCF-7 cells was prepared. One mg of Allium cepa. L's nanoparticles was taken and diluted in $1 \mathrm{ml}$ of dimethyl sulfoxide (DMSO), then diluted again in DMEM medium until the concentrations were $40 \mu \mathrm{g} / \mathrm{ml}, 80 \mu \mathrm{g} / \mathrm{ml}, 160 \mu \mathrm{g} / \mathrm{ml}$, and $320 \mu \mathrm{g} / \mathrm{ml}$. A positive control was made by diluting $1 \mathrm{mg}$ of cisplatin into $1 \mathrm{ml}$ DMSO in DMEM medium until the concentration was $4 \mu \mathrm{g} / \mathrm{ml}$. In this research, $100 \mu \mathrm{l}$ DMSO was used as a negative control.

Cells were seeded at the concentration of 5000 cells/100 $\mu$ DMSO in a 96-well plate. After $24 \mathrm{~h}$ of incubation, the medium was removed and the doses of the treatment were entered into the well with Allium cepa. L's nanoparticles doses $(50 \mu \mathrm{g} / \mathrm{ml}, 100 \mu \mathrm{g} / \mathrm{ml}, 150$ $\mu \mathrm{g} / \mathrm{ml}$, and $200 \mu \mathrm{g} / \mathrm{ml}$ ), cisplatin doses, and negative control doses. Each treatment was repeated three times and incubated at $37^{\circ} \mathrm{C}$ for $24 \mathrm{~h}$. After $24 \mathrm{~h}$ of incubation, liquid in the 96well was removed and MTT was added into all of the wells, then incubated at $37^{\circ} \mathrm{C}$ for $2 \mathrm{~h}$. Finally, $1 \%$ SDS was added to lyse the life cells so formazan could be read. Optical Density (OD) can be read by ELISA reader at $366 \mathrm{~nm}$.

The growth inhibition was determined using Table 1.

$$
\% \text { growth inhibition }=\frac{\mathrm{OD}_{\text {control }}-\mathrm{OD}_{\text {sample }}}{\mathrm{OD}_{\text {control }}} \times 100 \%
$$

Immunohistochemical analysis was performed to evaluate $\mathrm{Bcl}-2$ gene expression in MCF-7 cells which were treated with nanoparticles of Allium cepa. L extract (Marleen et al., 2011).

Immunohistochemical painting for Bcl-2 protein expression in MCF-7 cells was carried out in 4 treatment groups (cell control for Bcl-2, IC50, 2IC50, and 4IC50). This method used 6-well microplates with coverslips. MCF-7 cells and DMEM complete media of $500 \mu \mathrm{l}$ with $5 \times 104$ cells/well were incubated in $5 \% \mathrm{CO}_{2}$ at $37^{\circ} \mathrm{C}$ for 24 hours. Then, the DMEM medium was removed, nanoparticles extract and Allium cepa. $\mathrm{L}$ extracts were added according to 
dosage, and incubated in an incubator in $5 \% \mathrm{CO}_{2}$ at $37^{\circ} \mathrm{C}$ for 24 hours. After incubation, the media was removed again, fixed with $500 \mu \mathrm{L}$ methanol left at $37^{\circ} \mathrm{C}$ for 10 minutes, washed with tap water three times, and finally washed with PBS and left for 5 minutes.

The remaining PBS was removed, added with 30\% blocking solution (H2O2) with $10 \mathrm{ml}$ of methanol (1: 9), incubated for 10 minutes, washed with tap water, and the preparations were rinsed with PBS. Then, the preparations were added with $20 \mu \mathrm{l}$ of serum blocking and incubated for 10 minutes in a wet tray. $50 \mu \mathrm{l}$ of Bcl-2 antibodies were added and incubated for 1 hour in a wet tray. The preparations were washed with 2x PBS and added with $30 \mu \mathrm{l}$ of biotin (secondary $\mathrm{Ab}$ ), and incubated in a wet tray for 20 minutes. Next, $30 \mu \mathrm{l}$ of streptavidin was added and incubated in a wet tray for 10 minutes. The preparations were washed again with $2 x$ PBS and added with $30 \mu \mathrm{l}$ of substrate $(1000 \mu \mathrm{l}$ of buffer substrate and $10 \mu \mathrm{l}$ of diaminobenzidine), washed with tap water to clean the substrate and H\&E color, and left for 3 minutes. The preparations were washed with running water, drained, and pressed with mounting media. The preparations were covered with a coverslip and Bcl-2 protein expressions in the cell cytoplasm were observed using the inverted microscope at $1000 \mathrm{x}$ magnification.

\section{RESULTS OF STUDY}

The analysis results of TLC proved that Allium cepa. $L$ nanoparticles had active ingredients which can act as antioxidants and inhibit heat shock protein (HSP) in many malignant cancer cells, including breast cancer cells [11].

Table 1 - Phytochemical result of Allium cepa. $L$ nanoparticles

\begin{tabular}{|c|c|c|c|c|}
\hline No & Media & Mode & After Spray & Observation \\
\hline 1 & Flavonoids & + & & $\begin{array}{c}\text { With UV } 366 \mathrm{~nm} \\
\text { The color was light blue after being sprayed with } \\
\text { ammonia }\end{array}$ \\
\hline 2 & Tannins & + & 0 & $\begin{array}{c}\text { Visual } \\
\text { The color was black after being sprayed with } \mathrm{FeCl}_{3}\end{array}$ \\
\hline 3 & Saponins & + & & $\begin{array}{c}\text { Visual } \\
\text { The color was violet after being sprayed with } \\
\text { anisaldehyde }\end{array}$ \\
\hline
\end{tabular}

The results of the particle size analysis showed that the size distribution of Allium cepa. $\mathrm{L}$ nanoparticles were $84.7 \%$ with Z-Average $(\mathrm{d} . \mathrm{nm})$ of $336,8 \mathrm{~nm}$.

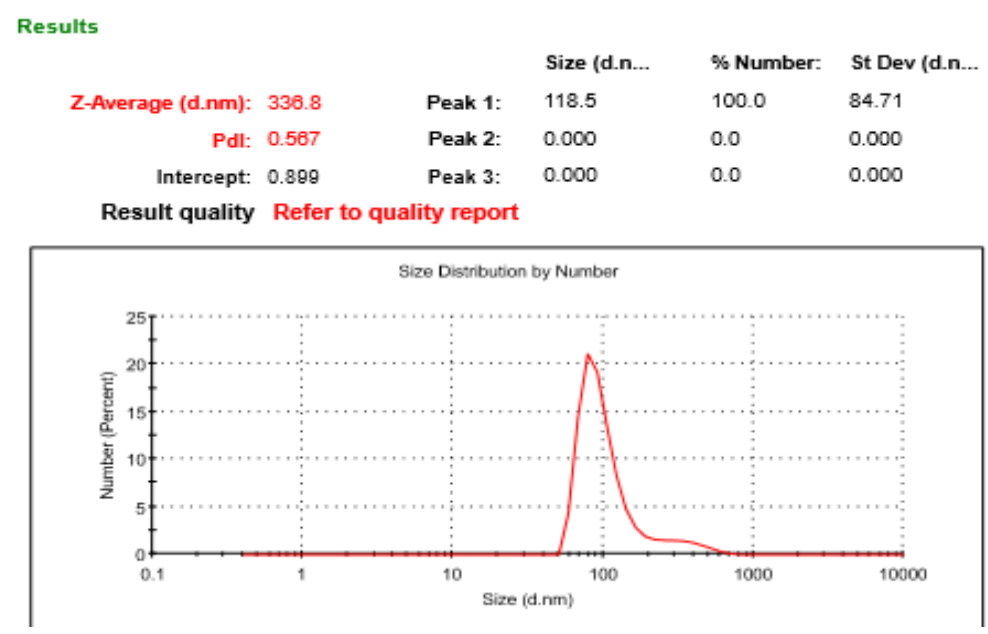

Figure 1 - Size distribution results of Allium cepa. L nanoparticles 


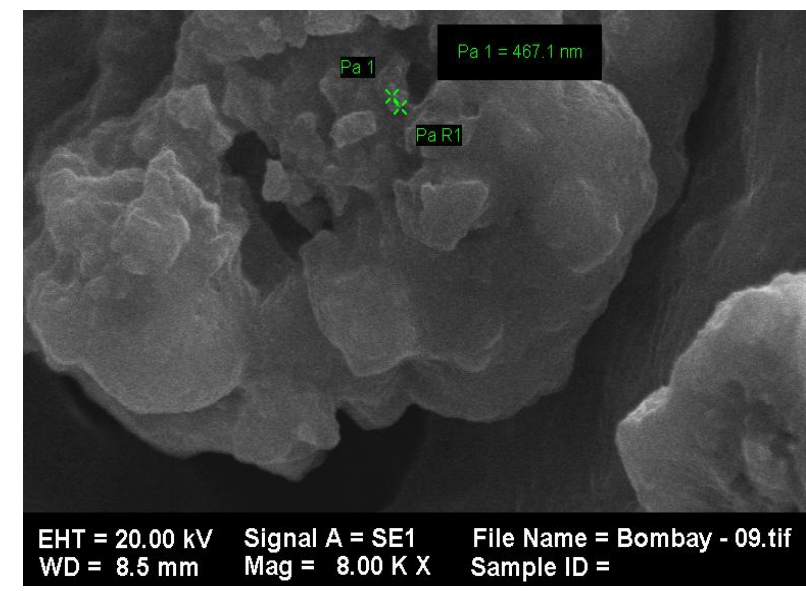

Figure 2 - Scanning electron microscopy $(8.000 x$ magnification)

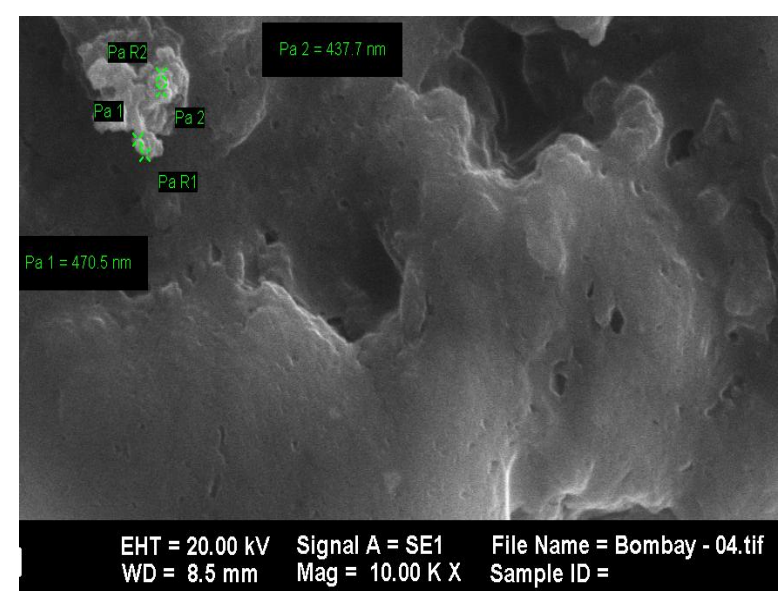

Figure 3 - Scanning electron microscopy (10.000x magnification)

The effective concentration of nanoparticles from Allium cepa. $L$ extract required for $50 \%$ inhibition of the cell viability was expressed as IC50. In this research, nanoparticles from Allium cepa. L extract could inhibit MCF cell growth with the IC50 value of $235 \mu \mathrm{g} / \mathrm{ml}$.

Table 2 - Cytotoxic activity of Allium cepa. L nanoparticles

\begin{tabular}{|c|c|c|c|c|c|}
\hline No & Type of treatment & $\begin{array}{c}\text { Therapy concentration } \\
(\mu \mathrm{g} / \mathrm{ml})\end{array}$ & $\begin{array}{c}\text { Cell death } \\
\%\end{array}$ & Linear Regression & $\mathrm{IC}_{50}$ \\
\hline 1 & \multirow{4}{*}{$\begin{array}{l}\text { Allium cepa. } \mathrm{L} \\
\text { nanoparticles }\end{array}$} & $40 \mu \mathrm{g} / \mathrm{ml}$ & $44.52 \%$ & \multirow{4}{*}{$\begin{array}{c}y=45.30+ \\
0.020 x\end{array}$} & \multirow{4}{*}{$\begin{array}{r}235 \\
\mu \mathrm{g} / \mathrm{m}\end{array}$} \\
\hline 2 & & $80 \mu \mathrm{g} / \mathrm{ml}$ & $47.63 \%$ & & \\
\hline 3 & & $160 \mu \mathrm{g} / \mathrm{ml}$ & $50.45 \%$ & & \\
\hline 4 & & $320 \mu \mathrm{g} / \mathrm{ml}$ & $51.08 \%$ & & \\
\hline 5 & Positive control (cisplatin) & $4 \mu \mathrm{g} / \mathrm{ml}$ & $15.61 \%$ & & \\
\hline 6 & Negative control (DMSO) & $100 \mu \mathrm{l}$ & $3.01 \%$ & & \\
\hline
\end{tabular}
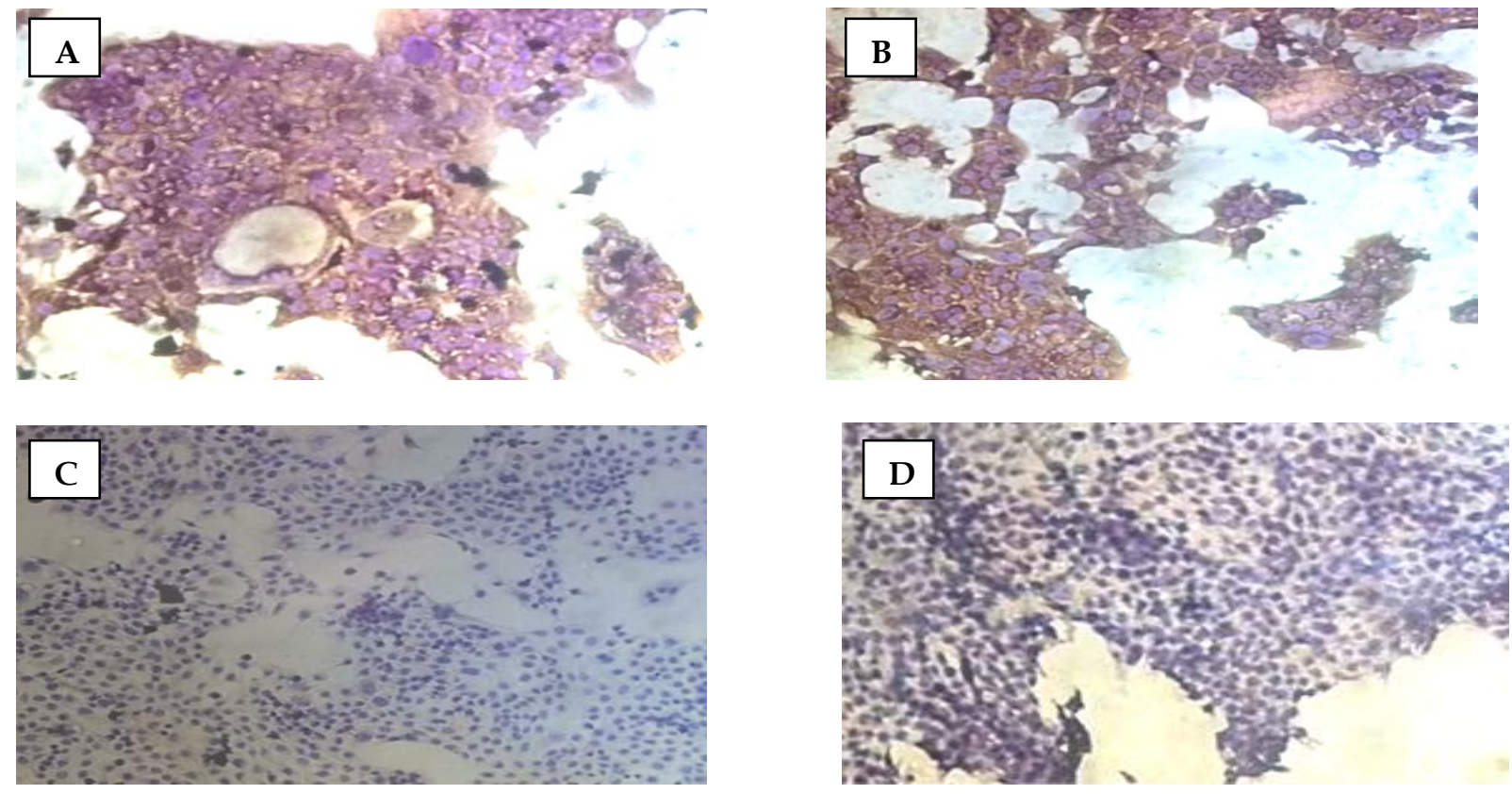

Figure 4 - Bcl-2 expression from MCF-7 cells from the immunohistochemical analysis given therapy with a series of concentrations of Allium cepa. L nanoparticles with 24-hour incubation time. A) Control of MCF-7 cells, B) therapeutic dose $\left(\mathrm{IC}_{50}\right)$ of $\left.235 \mu \mathrm{g} / \mathrm{mL}, \mathrm{C}\right)$, therapeutic dose $\left(2 \mathrm{IC}_{50}\right)$ of $\left.470 \mu \mathrm{g} / \mathrm{mL}, \mathrm{D}\right)$, therapeutic dose $\left(4 \mathrm{IC}_{50}\right)$ of $940 \mu \mathrm{g} / \mathrm{mL}$ 
The results of the scanning electron microscopy showed the surface visualization and the size of Allium cepa. L nanoparticles. SEM in this research used four magnifications of $8.000 x$ and $10.000 x$.

Observation on the Bcl-2 expression level was characterized by the brown color of the cell cytoplasm. When there was no Bcl-2 activity, the cytoplasm was purplish-blue in color according to the coloring used. This research used H\&E staining [12].

\section{DISCUSSION OF RESULTS}

The research results showed that cells treated by Allium cepa. $L$ nanoparticles after 24 $\mathrm{h}$ incubation time could suppress Bcl-2 expression and inhibit the proliferation of MCF-7 cells at concentrations of $40 \mu \mathrm{g} / \mathrm{ml}, 80 \mu \mathrm{g} / \mathrm{ml}, 160 \mu \mathrm{g} / \mathrm{ml}$ and $320 \mu \mathrm{g} / \mathrm{ml}$. The higher concentration caused a smaller number of living cells. Based on data about cell death percentages and after being calculated by linear regression statistics, the concentration of $235 \mu \mathrm{g} / \mathrm{ml}$ could inhibit 50\% MCF-7 cell proliferation.

Cytotoxicity of Allium cepa. L was influenced by the particle size because nanoparticles could release the drug 74 times faster [13] and the active ingredients contained in Allium cepa. L. Table 1, especially flavonoids. When flavonoids contained in Allium cepa. L was broken down, many quercetin compounds were found [3].

Quercetin is the aglycone form of a number of glycosides that can react as an anticancer to cell regulation and inhibit DNA topoisomerase enzymes cell cancer [14]. Quercetin is also capable of suppressing mutant p53 expression in breast cancer cells [15].

The results of the particle size analysis in this research showed that the size of the obtained nanoparticles had a Z-average of $336,8 \mathrm{~nm}$. These results are in line with a theory stating that the good size range of a nanoparticle is $336 \mathrm{~nm}$ [16].

\section{ACKNOWLEDGMENTS}

This work was conducted in Department of Veterinary Clinical Pathology, Faculty of Veterinary Medicine, Airlangga University; Department of Phytochemistry, Faculty of Pharmacy, Airlangga University and Department of Parasitology, Faculty of Medicine, Gadjah Mada University.

\section{REFERENCES}

1. Veta, M., Van, D.P.J., Willems., S.M, Wang, H., Madabhushi, A., Cruz-Roa, A., Gonzales, F., Larsen, A.B.L, Vestergaard, J.S, Dahl, A.B et al. 2014. Assesment of algorithms for mitosis detection in breast cancer histophatology images. Med Ima anal.doi:10.1016/j.media.2014.11.010.

2. Priosoeryanto, B.P. 2014. Penyakit Tumor Pada Hewan: Biologi dan Upaya Penanganannya, Institut Pertanian Bogor. Bogor.

3. Murtihapsari, 2012. Analisis Senyawa Bawang Bombay (Allium cepa. L) Melalui Uji Multifragmen Separatif dan Spektrofotometer. Fakultas MIPA. Universitas NegeriPapua. Manokwari. Papua Barat.

4. Oesterreich, S., Weng, C.N., Qui, M., et al. 1993. The small heat shock protein hsp27 is correlated with growth and drug resistance in human breast cancer cell lines. Cancer Res;53:4443-4448.

5. Mukherjee, A., Anisur, R.K.B. 2014. Quercetin Down-regulates IL-6/STAT-3 Signal to Induce Mithocondrial-mediated Apoptosis in a Non Small Cell Lung Cancer Cell Line, A549. Cytogenetic and Molecular Biology Laboratory. University of Kalyani. India.

6. Sun, H.X., Xie, Y. And Ye, Y.P. 2009. Advances The Adjuvants Bassed in Saponins. Vaccine 27:1787-1796

7. Bawadi, H.A., Bansode, R.R, Trappey, A., Truax, R.E and Losso, J.N. 2005. Tannininhibition activity to $\mathrm{CaCo}_{2}, \mathrm{MCF}-7$ and Hs578T and DU 145 from black peanutett, 218:153-162. 
8. Kutlu, T. dan Isil, Y. 2015. Agen Antikanker: Saponin dan Tannin. Jurnal Kimia Biologi Internasional. Volume 9.332-340.

9. Sun, HX., Y. Xie dan YP Ye. 2009. Kemajuan dalam ajuvan berbasis saponin. Vaksin 27:1787-1796.

10.Fulda, S., Meyer, E. and Debatin. K.M. 2000. Inhibition of TRAIL induced apoptosis by $\mathrm{Bcl}-2$ Overexpression. Oncogene., 21, 2283-2294.

11. Hansen, R.K, Oesterrich, S., Lemieux, P. 1997. Quercetin inhibits heat shock protein induction but not heat shock factor DNA-binding in human breast carcinoma cells. Biochem Biophys Res Commun; 239:851-856.

12.Minn, A.J., Velez, P., Schendel, S.L., Liang, H., Muchmore, S.W., Fesik, S.W., Fill M. and Thompson, C.B. 1997. Bcl-x (L) form an ion channel in synthetic lipid membranes. Nature., 385(6614):353-357.

13.Dewandari, K.T., Yuliani, S. dan Yasni, S. 2013. Ekstraksi dan Karakterisasi Nanopartikel Ekstrak Sirih Merah. Pasca Panen. Volume 10.

14. Hegnauer, R.Nd. 2012. Chemical Characters in Plant Taxonomy: some Possibilities and Limitations. June.2.2012

15.Lamson, D.W., Brignall, M.S. 2000. Antioxidant and Cancer, part3:Quercetin, Alternative Medicine Review Volume 3 Number 3.

16.Winarno, F.G. and Fernandez, I.E. 2010. Nanotekhnologi Bagi Industri Pangan dan Kemasan. Bogor:Mbrio Press. 